\title{
Prenylated Diresorcinols Inhibit Bacterial Quorum Sensing
}

By: Noemi D. Paguigan, José Rivera-Chávez, Justin J. Stempin, Mario Augustinović, Aleksandra I. Noras, $\underline{\text { Huzefa A. Raja, Daniel A. Todd, Kathleen D. Triplett, Cynthia Day, Mario }}$ Figueroa, Pamela R. Hall, Nadja B. Cech, and Nicholas H. Oberlies

This document is the Accepted Manuscript version of a Published Work that appeared in final form in Journal of Natural Products, copyright (C) American Chemical Society after peer review and technical editing by the publisher. To access the final edited and published work see:

Paguigan, N.D., Rivera-Chávez, J., Stempin, J.J., Augustinović, M., Noras, A.I., Raja, H.A., Todd, D.A., Triplett, K.D., Day, C., Figueroa, M., Hall, P.R., Cech, N.B., Oberlies, N.H. (2019). Prenylated Diresorcinols Inhibit Bacterial Quorum Sensing. Journal of Natural Products.

Made available courtesy of American Chemical Society: http://dx.doi.org/10.1021/acs.jnatprod.8b00925

$* * *$ (C) American Chemical Society. Reprinted with permission. No further reproduction is authorized without written permission from American Chemical Society. This version of the document is not the version of record. Figures and/or pictures may be missing from this format of the document. ***

\section{Abstract:}

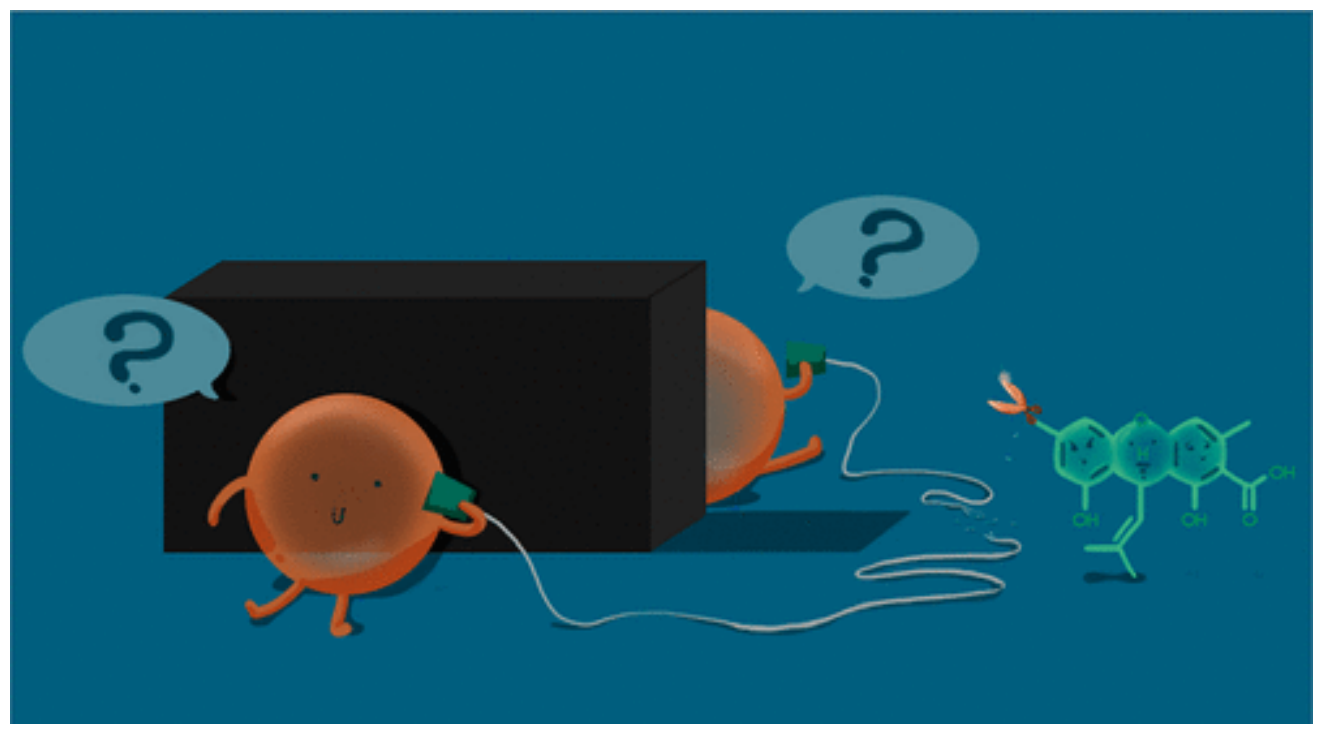

Current treatment options for bacterial infections are dependent on antibiotics that inhibit microbial growth and viability. These approaches result in the evolution of drug-resistant strains of bacteria. An anti-infective strategy that is less likely to lead to the development of resistance is the disruption of quorum sensing mechanisms, which are involved in promoting virulence. The goal of this study was to identify fungal metabolites effective as quorum sensing inhibitors. Three new prenylated diresorcinols (1-3), along with two known compounds, (4R)-regiolone and decarboxycitrinone, were isolated from a freshwater fungus (Helotiales sp.) from North 
Carolina. Their structures were assigned on the basis of HRESIMS and NMR experiments. The structure of compound 1 was confirmed via X-ray diffraction analysis, and its absolute configuration was established by TDDFT-ECD and optical rotation calculations. Compounds 13 suppressed quorum sensing in a clinical isolate of methicillin-resistant Staphylococcus aureus (MRSA), with IC50 values ranging from 0.3 to $12.5 \mu \mathrm{M}$. These compounds represent potential leads in the development of antivirulence therapeutics.

Keywords: Bacterial quorum sensing | Pathogens | Bacterial infections | Antibiotics

\section{Article:}

Methicillin-resistant Staphylococcus aureus (MRSA) infections are a growing public health burden, exacerbated by the emergence of community-associated MRSA, which causes significant morbidity and mortality worldwide.(1,2) An estimated 150000 patients are affected annually across Europe from MRSA infections,(3) and Asia has one of the highest prevalence of MRSA globally.(4) In the United States, the Centers for Disease Control and Prevention have estimated at least 80000 incidences of severe MRSA infections per year, with about $10 \%$ to $15 \%$ of these being fatal.(5) To begin to address this urgent health threat, an executive order was issued by the White House in 2014, launching an interagency task force charged with developing a five-year national action plan to combat the emergence and spread of antibiotic-resistant bacteria.(6) Part of the strategy hinges upon the acceleration of research and development of new antibacterial drugs and other novel therapeutics that would limit the use of antibiotics, while, concomitantly, easing the complications of drug-resistant pathogens.(6) In 2017, the World Health Organization seemed to support these ideas, as they listed MRSA as one of the priority pathogens that cause the greatest threat to human health, and they too called for the development of new antibiotics and better treatment options to reduce the severity of the impact of these pathogens.(7)

Several alternative approaches have been explored for combating bacterial infections, and one of these is focused on blocking bacterial pathogenesis without killing or inhibiting bacterial growth.(8-14) By controlling bacterial virulence, it has been proposed that selective pressure toward resistance development would be prevented or at least minimized. The introduction of antivirulence therapeutics could be an effective strategy to decrease the occurrence and severity of drug-resistant infections while reducing reliance on antibiotics. $(8,9)$ In $S$. aureus, the expression of virulence factors driving invasive infection is mediated by the accessory gene regulator (agr) operon.(15) This operon encodes a quorum sensing system composed of four proteins, AgrD, AgrB, AgrC, and AgrA (Figure 1). AgrD is a linear precursor peptide that is cleaved, cyclized, and then secreted through AgrB as an autoinducing peptide (AIP). Secreted AIP binds the receptor histidine kinase AgrC on the bacterial surface, resulting in phosphorylation and activation of the transcription factor AgrA. In turn, AgrA binds the divergent promoters of the operon, $\mathrm{P} 2$ and $\mathrm{P} 3$, resulting in continued expression of the four protein components of the operon (via P2) as well as expression of RNAIII (via P3), a small regulatory RNA that controls expression of over 200 virulence-related genes.(16) AgrA also directly controls expression of phenol-soluble modulin (PSM) virulence factors, independent of 
RNAIII.(17) Disrupting agr signaling is one promising strategy to combat invasive $S$. aureus infections.(18)

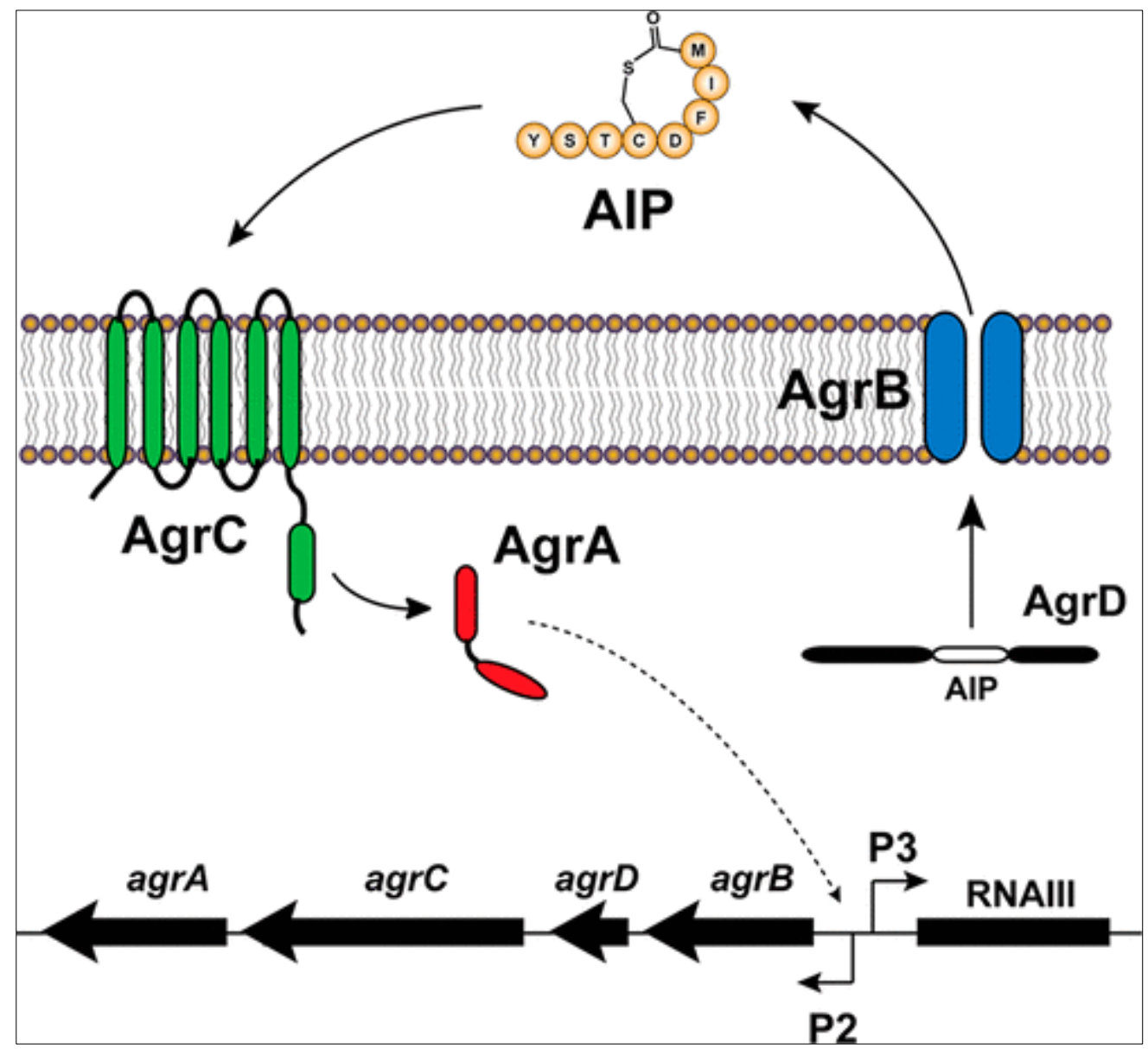

Figure 1. The agr system in Staphylococcus aureus. The activity of this system is initiated when AIP binds to AgrC, which in turn induces phosphorylation of AgrA, activating the P2 and P3 promoters. The $\mathrm{P} 3$ promotor regulates the downstream production of virulence factors that are associated with the pathogenicity of $S$. aureus infections. Activation of the $\mathrm{P} 2$ promoter causes transcription of the genes that encode for the components of the agr system, thereby acting as a positive feedback loop that further induces the production of virulence factors. AgrB is responsible for signal biosynthesis, cyclizing and secreting the AgrD precursor as AIP. Reproduced with permission from Todd et al.(19) Copyright 2017 American Society for Microbiology.

Natural products continue to be a prolific source of therapeutics, as a large extent of the world's biodiversity has been untapped for chemical diversity and biological activity.(20,21) Recent studies have identified a few fungal metabolites with antivirulence activity against $S$. aureus, including ambuic acid(22) and $\omega$-hydroxyemodin. $(23,24)$ It is well established that bacteria and fungi compete with each other in their natural environment and engage in communication via chemical signals.(25) These interactions may result in changes in the biosynthesis of small molecules that affect the pathogenicity of one or both organisms. This concept led us to 
hypothesize that some fungi may inherently biosynthesize compounds that modulate bacterial quorum sensing, thereby constituting a potential source of antivirulence agents.

Freshwater ascomycetes, an ecological group of fungi with about 1500 described species to date, $(26,27)$ are adapted to lentic and lotic habitats, and they play an important role in the decomposition of organic matter.(26-29) Our earlier studies of freshwater ascomycetes from North Carolina have been productive from both mycological and chemical perspectives,(30-36) but far from exhaustive, representing a minor fraction of the potential of these organisms. As part of ongoing studies to further explore the chemical diversity of these organisms and to identify fungal metabolites that target virulence in MRSA, we investigated an isolate identified as Helotiales sp. (accessioned as strain G730). A solid-phase culture of G730 yielded five organic compounds, three of which were new prenylated diresorcinols. The structures of all compounds were elucidated via NMR and HRESIMS. The structural assignments of 1 based on NMR data were confirmed by X-ray crystallography, and the absolute configuration of 1 was determined using electronic circular dichroism (ECD) spectroscopy combined with time-dependent density functional theory and quantum chemical ECD calculations (TDDFT-ECD). The new prenylated diresorcinols (1-3) were tested for inhibition of $a g r$ signaling against a well-characterized MRSA strain, USA300 LAC (AH1263),(19,37) and showed promising results, with significant reductions in AIP production, and transcription of agr-regulated virulence genes.

\section{Results and Discussion}

The fungal isolate (strain G730) was isolated from submerged wood that was collected in a freshwater lake in Hanging Rock State Park, North Carolina. An organic extract from G730 showed favorable antivirulence activity $(89 \%$ inhibition at $10 \mu \mathrm{g} / \mathrm{mL})$ when tested for inhibition of AIP production against a clinical MRSA isolate, USA300 LAC (AH1263).(38) Bioactivitydirected purification of the extract led to the isolation of three new prenylated diresorcinols (13), which were ascribed the trivial names leotiomycenes A-C, respectively. Moreover, the known compounds (4R)-regiolone and decarboxycitrinone were also isolated and identified based on NMR, HRESIMS, and optical rotation data, all of which were in agreement with the literature. $(39,40)$ 

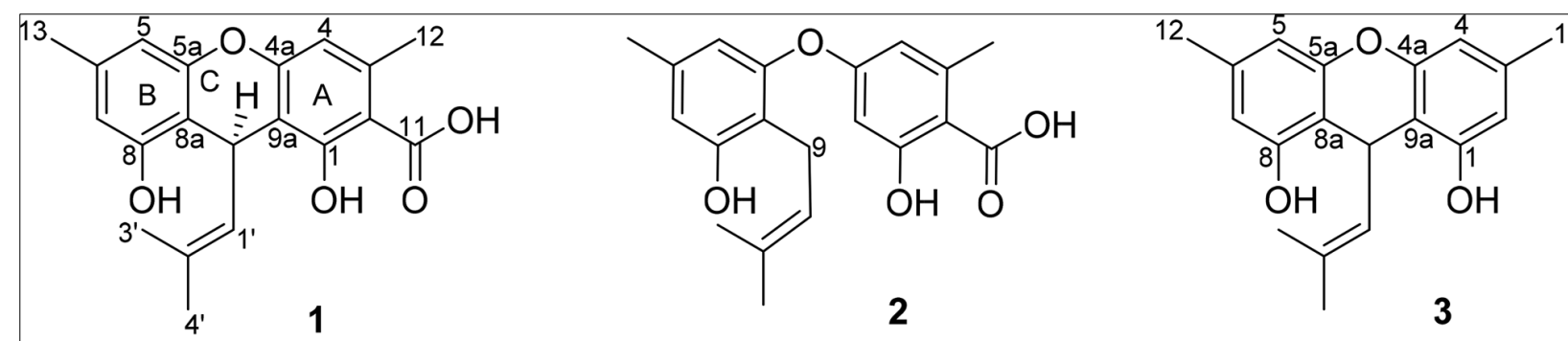<smiles>COc1cc(O)cc2c1C(=O)c1cc(CO)cc(O)c1C2=O</smiles>

Leotiomycene A (1) was obtained as yellowish-white, amorphous powder. The molecular formula for 1 was established as $\mathrm{C}_{20} \mathrm{H}_{20} \mathrm{O}_{5}$ based on HRESIMS and NMR data, indicating an index of hydrogen deficiency of 11 . Analysis of the ${ }^{1} \mathrm{H}$ and ${ }^{13} \mathrm{C}$ NMR data indicated the presence of 20 carbon atoms, consisting of four methyl groups, five methines (three aromatic, one olefinic, and one aliphatic), and 11 nonprotonated carbons (nine aromatic, one olefinic, and one carbonyl). Based on 1D and 2D NMR data (Table 1), three partial structures of 1 were elucidated (Figure 2).

Table 1. ${ }^{1} \mathrm{H}(400 \mathrm{MHz})$ and ${ }^{13} \mathrm{C}(100 \mathrm{MHz})$ NMR Data for Compounds 1 and 2 in $\mathrm{CDCl}_{3}$

\begin{tabular}{|c|c|c|c|c|c|c|}
\hline & \multicolumn{3}{|l|}{1} & \multicolumn{3}{|l|}{2} \\
\hline position & бc, type & $\begin{array}{l}\delta_{\mathrm{H}}, \text { mult } \\
(J \text { in } \mathrm{Hz})\end{array}$ & HMBC & бc, type & $\begin{array}{l}\delta_{H}, \text { mult } \\
(J \text { in } \mathrm{Hz})\end{array}$ & HMBC \\
\hline 1 & 164.1, C & & & $166.3, \mathrm{C}$ & & \\
\hline 2 & 105.4, C & & & 105.0, C & & \\
\hline 3 & 142.6, C & & & 145.3, C & & \\
\hline 4 & $\begin{array}{l}111.8, \\
\mathrm{CH}\end{array}$ & $6.48, \mathrm{~s}$ & $\begin{array}{l}2,4 a, 9 a \\
11,12\end{array}$ & $\begin{array}{l}112.5, \\
\mathrm{CH}\end{array}$ & $\begin{array}{l}6.37, \mathrm{~d} \\
(2.4)\end{array}$ & $2,4 a, 9 a$ \\
\hline $4 \mathrm{a}$ & $155.9, \mathrm{C}$ & & & 164.2, C & & \\
\hline 5 & $\begin{array}{l}109.8, \\
\mathrm{CH}\end{array}$ & 6.52, br s & $\begin{array}{l}5 \mathrm{a}, 7,8, \\
8 \mathrm{a}, 13\end{array}$ & $\begin{array}{l}114.7, \\
\mathrm{CH}\end{array}$ & 6.43 , br s & $\begin{array}{l}5 a, 7,8 a, \\
13\end{array}$ \\
\hline $5 \mathrm{a}$ & $150.7, \mathrm{C}$ & & & $152.3, \mathrm{C}$ & & \\
\hline 6 & 138.6, C & & & $138.4, \mathrm{C}$ & & \\
\hline 7 & $\begin{array}{l}112.3, \\
\mathrm{CH}\end{array}$ & 6.45, br s & $5,8,8 \mathrm{a}, 13$ & $\begin{array}{l}114.1, \\
\mathrm{CH}\end{array}$ & 6.56 , br s & $\begin{array}{l}5,8,8 \mathrm{a}, \\
13\end{array}$ \\
\hline 8 & $154.3, \mathrm{C}$ & & & $156.0, \mathrm{C}$ & & \\
\hline $8 \mathrm{a}$ & 108.5, C & & & 117.0, C & & \\
\hline 9 & $\begin{array}{l}28.3 \\
\mathrm{CH}\end{array}$ & $\begin{array}{l}4.96, \mathrm{~d} \\
(10.4)\end{array}$ & $\begin{array}{l}1,4 a, 5 a \\
8,8 a, 9 a \\
1^{\prime}, 2^{\prime}\end{array}$ & $\begin{array}{l}23.1, \\
\mathrm{CH}_{2}\end{array}$ & $\begin{array}{l}3.24, \mathrm{~d} \\
(7.1)\end{array}$ & $\begin{array}{l}5 a, 8,8 a, \\
1^{\prime}, 2^{\prime}\end{array}$ \\
\hline
\end{tabular}




\begin{tabular}{|l|l|l|l|l|l|l|}
\hline $9 \mathrm{a}$ & $109.1, \mathrm{C}$ & & & $\begin{array}{l}102.0, \\
\mathrm{CH}\end{array}$ & $\begin{array}{l}6.20, \mathrm{~d} \\
(2.4)\end{array}$ & $\begin{array}{l}1,2,4, \\
4 \mathrm{a}\end{array}$ \\
\hline 11 & $175.4, \mathrm{C}$ & & & $175.0, \mathrm{C}$ & & \\
\hline 12 & $\begin{array}{l}24.4, \\
\mathrm{CH}_{3}\end{array}$ & $2.58, \mathrm{~s}$ & $\begin{array}{l}1,2,3,4, \\
11\end{array}$ & $\begin{array}{l}24.6, \\
\mathrm{CH}_{3}\end{array}$ & $2.57, \mathrm{~s}$ & $\begin{array}{l}2,3,4, \\
11,\end{array}$ \\
\hline 13 & $\begin{array}{l}21.4, \\
\mathrm{CH}_{3}\end{array}$ & $2.28, \mathrm{~s}$ & $5,6,7$ & $\begin{array}{l}21.3, \\
\mathrm{CH}_{3}\end{array}$ & $2.26, \mathrm{~s}$ & $5,6,7$ \\
\hline $1^{\prime}$ & $\begin{array}{l}125.4, \\
\mathrm{CH}\end{array}$ & $5.01, \mathrm{dm}$ & $3^{\prime}, 4^{\prime}$ & $\begin{array}{l}121.3, \\
\mathrm{CH}\end{array}$ & $\begin{array}{l}5.16, \mathrm{tm} \\
(7.1)\end{array}$ & $3^{\prime}, 4^{\prime}, 9$ \\
\hline $2^{\prime}$ & $132.6, \mathrm{C}$ & & & $135.3, \mathrm{C}$ & & \\
\hline $3^{\prime}$ & $\begin{array}{l}18.2, \\
\mathrm{CH}_{3}\end{array}$ & $2.04, \mathrm{~s}$ & $1^{\prime}, 2^{\prime}, 4^{\prime}$ & $\begin{array}{l}18.0, \\
\mathrm{CH}_{3}\end{array}$ & $1.71, \mathrm{br} \mathrm{s}$ & $1^{\prime}, 2^{\prime}, 4^{\prime}$ \\
\hline $4^{\prime}$ & $\begin{array}{l}25.9, \\
\mathrm{CH}_{3}\end{array}$ & $1.69, \mathrm{~s}$ & $1^{\prime}, 2^{\prime}, 3^{\prime}$ & $\begin{array}{l}25.9, \\
\mathrm{CH}_{3}\end{array}$ & $1.69, \mathrm{br} \mathrm{s}$ & $1^{\prime}, 2^{\prime}, 3^{\prime}$ \\
\hline $1-\mathrm{OH}$ & & $11.90, \mathrm{~s}$ & $1,2,4 \mathrm{a}, 9 \mathrm{a}$ & & $11.44, \mathrm{~s}$ & $\begin{array}{l}1,2,4 \mathrm{a}, \\
9 \mathrm{a}\end{array}$ \\
\hline $8-\mathrm{OH}$ & & & & & $5.26, \mathrm{br} \mathrm{s}$ & \\
\hline
\end{tabular}

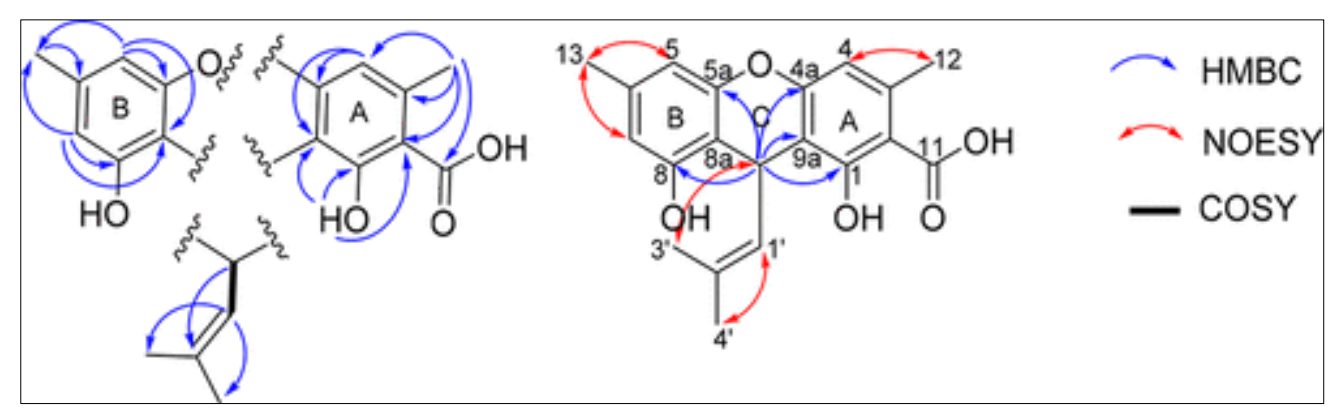

Figure 2. Partial structures and selected HMBC, COSY, and NOESY correlations of compound 1.

Resonances for a pentasubstituted and a 1,2,3,5-tetrasubstituted aromatic ring were identified based on the singlet resonance at $\delta_{\mathrm{H}} 6.48(\mathrm{H}-4)$ for the former and signals for meta-coupled protons at $\delta_{\mathrm{H}} 6.52(\mathrm{H}-5)$ and $6.45(\mathrm{H}-7)$ for the latter (both observed as broad singlets). Furthermore, the ${ }^{13} \mathrm{C}$ NMR shifts $\left(\delta_{\mathrm{C}} 164.1,155.9,150.7,154.3\right)$ observed for the aromatic carbons $\mathrm{C}-1, \mathrm{C}-4 \mathrm{a}, \mathrm{C}-5 \mathrm{a}$, and $\mathrm{C}-8$, respectively, indicated that rings $\mathrm{A}$ and $\mathrm{B}$ were both dioxygenated. HMBC correlations from $\mathrm{H}-4$ to $\mathrm{C}-4 \mathrm{a} / \mathrm{C}-9 \mathrm{a}$ and $\mathrm{H}_{3}-12$ to $\mathrm{C}-2 / \mathrm{C}-3 / \mathrm{C}-4 / \mathrm{C}-11$, in combination with the NOESY cross-peaks between $\mathrm{H}-4$ and $\mathrm{H}_{3}-12$, and the presence of a phenol resonance at $\delta_{\mathrm{H}} 11.90(1-\mathrm{OH})$, hydrogen bonded to the carboxylic acid carbonyl at $\delta_{\mathrm{C}} 175.4(\mathrm{C}$ 11), allowed the assembly of ring A. Similarly, ring B was assigned based on the HMBC correlations from $\mathrm{H}-5$ to $\mathrm{C}-5 \mathrm{a} / \mathrm{C}-8 \mathrm{a} / \mathrm{C}-13$ and from $\mathrm{H}-7$ to $\mathrm{C}-8 / \mathrm{C}-8 \mathrm{a} / \mathrm{C}-13$ and the NOESY crosspeaks observed between $\mathrm{H}_{3}-13$ and both $\mathrm{H}-5$ and $\mathrm{H}-7$. The remaining fragment in $\mathbf{1}$ was elucidated based on HMBC and COSY experiments, and this was attached to C-8a of ring B and C-9a of ring A, as supported by HMBC correlations observed from H-9 to C-1/C-4a/C-5a/C-8/C$8 \mathrm{a} / \mathrm{C}-9 \mathrm{a}$. Consideration of the molecular formula, the degrees of unsaturation, and the deshielded resonances of $\mathrm{C}-4 \mathrm{a}\left(\delta_{\mathrm{C}} 155.9\right)$ and $\mathrm{C}-5 \mathrm{a}\left(\delta_{\mathrm{C}} 150.7\right)$ indicated an ether linkage between rings $\mathrm{A}$ 
and $\mathrm{B}$. This latter consideration formed ring $\mathrm{C}$, thereby establishing the $9 H$-xanthene skeleton. Altogether, these correlations resulted in the planar structure of the new fungal metabolite $\mathbf{1}$. During the course of this study, crystals were obtained from a concentrated 1:1 acetone-hexane solution of 1. X-ray diffraction analysis of a suitable crystal confirmed the proposed structural assignments of $\mathbf{1}$, as shown in Figure 3.

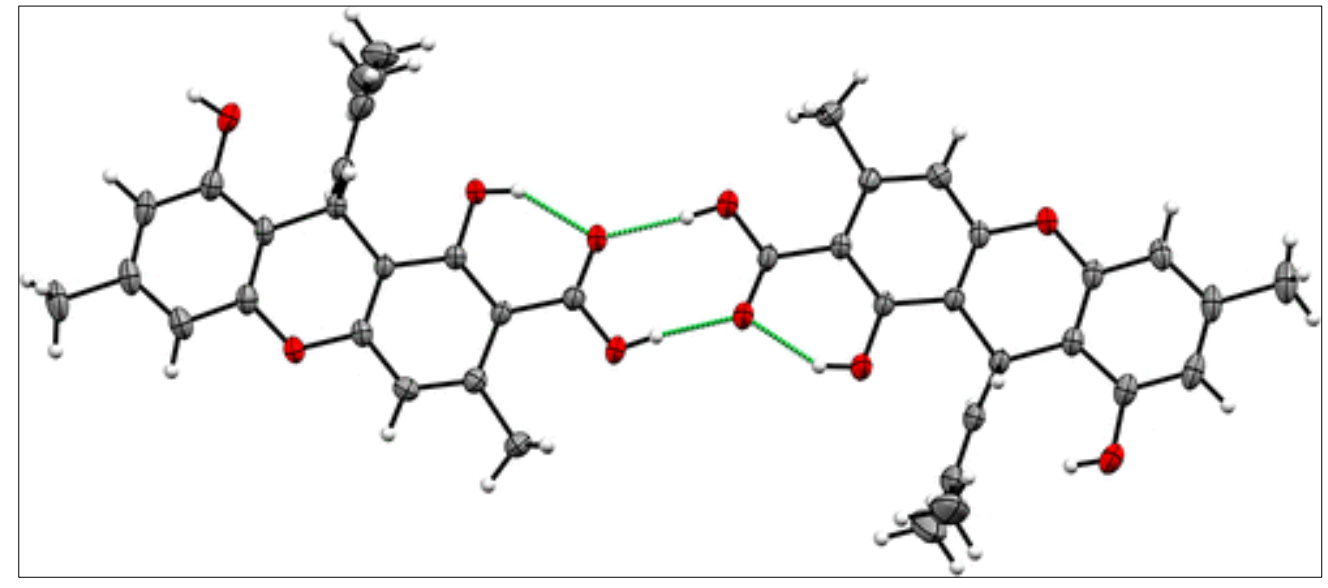

Figure 3. ORTEP representation of two molecules of compound 1. Intra- and intermolecular Hbonding is indicated by green dashed lines.

To determine the absolute configuration of $\mathbf{1}$, the experimental ECD spectrum of $\mathbf{1}$ and the TDDFT ECD spectra for enantiomers $9 R$ and $9 S$ of 1 were compared. In brief, TDDFT calculations were performed by minimization of the structure of each enantiomer, followed by a conformational search using a Monte Carlo protocol. Conformers for each enantiomer that were within a $10 \mathrm{kcal} / \mathrm{mol}$ window were selected and reoptimized using DFT calculations at the B3LYP/6-311+G $(2 d, p)$ level of theory. Finally, the theoretical ECD spectra of each conformer of the $9 R$ and 9 Senantiomers were calculated using TDDFT at the same level of theory with the polarizable continuum model in $\mathrm{CH}_{3} \mathrm{CN}$. The specific rotation values for enantiomers $9 R$ and $9 S$ were also calculated. The calculated ECD spectrum based on TDDFT for the $9 S$ enantiomer matched well with the experimentally measured data, which displayed a positive and a negative Cotton effect at $\sim 210$ and $\sim 230 \mathrm{~nm}$, respectively (Figure 4). Furthermore, the calculated specific rotation value for the $9 S$ enantiomer $\left([\alpha]^{25}{ }_{D}+117\right)$ was in agreement with both the experimental data $\left([\alpha]^{25} \mathrm{D}+90\right)$ and the X-ray diffraction analysis. Thus, the absolute configuration of $\mathbf{1}$ at C-9 was assigned as $S$. 


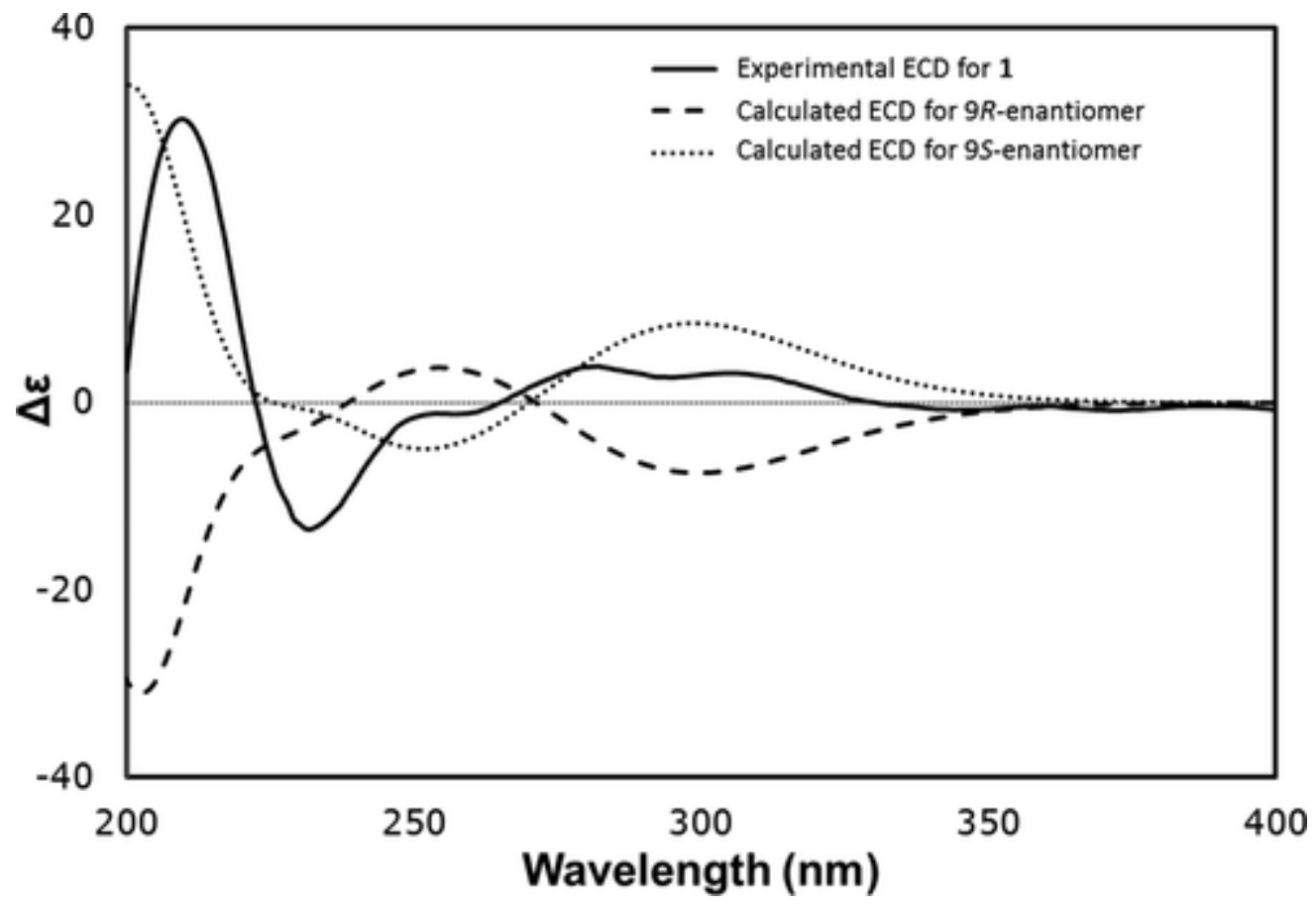

Figure 4. Comparison of the experimental and calculated (at the B3LYP/6-311+G(2d,p) level) ECD spectra of 1 in $\mathrm{CH}_{3} \mathrm{CN}$.

A molecular formula consisting of $\mathrm{C}_{20} \mathrm{H}_{22} \mathrm{O}_{5}$ (10 unsaturations) was assigned for leotiomycene $\mathrm{B}$ (2) based on HRESIMS and NMR data (Table 1). The ${ }^{1} \mathrm{H}$ NMR spectrum of $\mathbf{2}$ displayed signals similar to those of $\mathbf{1}$, with notable differences including an additional aromatic proton signal $\mathrm{H}$ $9 \mathrm{a}\left(\delta_{\mathrm{H}} 6.20, \mathrm{~d}, J=2.4 \mathrm{~Hz}\right)$ and a more shielded signal for methylene protons $\mathrm{H}_{2}-9\left(\delta_{\mathrm{H}} 3.24, \mathrm{~d}, J=\right.$ $7.1 \mathrm{~Hz})$ relative to the $\mathrm{H}-9$ methine $\left(\delta_{\mathrm{H}} 4.96, \mathrm{~d}, J=10.4 \mathrm{~Hz}\right)$ in 1 . Considering these changes in the ${ }^{1} \mathrm{H}$ NMR spectrum and the decrease of unsaturation number in $\mathbf{2}$ relative to $\mathbf{1}$, the lack of a $9 H$-xanthene skeleton was proposed for $\mathbf{2}$. This was confirmed via the observed meta coupling $(J=2.4 \mathrm{~Hz})$ between $\mathrm{H}-9 \mathrm{a}$ and $\mathrm{H}-4\left(\delta_{\mathrm{H}} 6.37, \mathrm{~d}\right)$ and the $\mathrm{HMBC}$ correlations from $\mathrm{H}-9 \mathrm{a}$ to C-1/C2/C-4/C-4a and from H-9 to C-5a/C-8/C-8a. The HMBC correlations for 2 were nearly identical to those observed with $\mathbf{1}$, with the main difference being the lack of cross-peaks from $\mathrm{H}_{2}-9$ to C9a. In total, these data suggested $\mathbf{2}$ to be the 9,9a-seco derivative of $\mathbf{1}$.

Leotiomycene $\mathrm{C} \mathrm{(3)}$ was isolated as an optically inactive white powder. Its molecular formula, $\mathrm{C}_{19} \mathrm{H}_{20} \mathrm{O}_{3}$, established from HRESIMS and NMR data (Table 2), indicated a structure with an index of hydrogen deficiency of 10 . These data were consistent with compound $\mathbf{3}$ being a decarboxylated analogue of $\mathbf{1}$. The ${ }^{1} \mathrm{H}$ NMR spectrum of $\mathbf{3}$ displayed only one set of signals for the meta-coupled protons $\mathrm{H}-2 / 7$ and $\mathrm{H}-4 / 5$ (broad singlets at $\delta_{\mathrm{H}} 6.36$ and 6.49 , respectively) in rings $\mathrm{A}$ and $\mathrm{B}$ and for the methyl $\mathrm{H}_{3}-11 / 12\left(\delta_{\mathrm{H}} 2.26\right.$, s) and hydroxy $1-\mathrm{OH} / 8-\mathrm{OH}\left(\delta_{\mathrm{H}} 4.88, \mathrm{~s}\right)$ groups. Likewise, the ${ }^{13} \mathrm{C}$ NMR spectrum displayed only one set of signals for all of the aromatic carbons C-1/8, C-2/7, C-3/6, C-4/5, C-4a/5a, and C-8a/9a ( $\delta_{\mathrm{C}} 154.3,111.2,138.6,109.8,151.6$, and 107.5, respectively) in both rings. Based on these data, along with the analysis of the $2 \mathrm{D}$ NMR data, it was concluded that a decarboxy analogue of $\mathbf{1}$ at C-2 rendered the two halves 
of $\mathbf{3}$ symmetrical, resulting in the absence of a stereogenic center at position C-9 in $\mathbf{3}$, which was supported by the lack of optical activity observed for this compound.

Table 2. ${ }^{1} \mathrm{H}(500 \mathrm{MHz})$ and ${ }^{13} \mathrm{C}(125 \mathrm{MHz}) \mathrm{NMR}$ Data for Compound 3 in $\mathrm{CDCl}_{3}$

\begin{tabular}{|l|l|l|l|}
\hline position & $\boldsymbol{\delta}$, type & $\boldsymbol{\delta} \mathbf{H}$, mult $(\boldsymbol{J}$ in Hz) & HMBC \\
\hline $1 / 8$ & $154.3, \mathrm{C}$ & & \\
\hline $2 / 7$ & $111.2, \mathrm{CH}$ & $6.36, \mathrm{br} \mathrm{s}$ & $1,4,9 \mathrm{a}, 11 / 5,8,8 \mathrm{a}, 12$ \\
\hline $3 / 6$ & $138.6, \mathrm{C}$ & & $2,4 \mathrm{a}, 9 \mathrm{a}, 11 / 7,5 \mathrm{a}, 8 \mathrm{a}, 12$ \\
\hline $4 / 5$ & $109.8, \mathrm{CH}$ & $6.49, \mathrm{br} \mathrm{s}$ & \\
\hline $4 a / 5 \mathrm{a}$ & $151.6, \mathrm{C}$ & & $1 / 8,4 \mathrm{a} / 5 \mathrm{a}, 8 \mathrm{a} / 9 \mathrm{a}, 1^{\prime}, 2^{\prime}$ \\
\hline $8 a / 9 \mathrm{a}$ & $107.5, \mathrm{C}$ & & $2,3,4 / 5,6,7$ \\
\hline 9 & $28.7, \mathrm{CH}$ & $4.91, \mathrm{~d}(10.4)$ & $3^{\prime}, 4^{\prime}$ \\
\hline $11 / 12$ & $21.3, \mathrm{CH}_{3}$ & $2.26, \mathrm{~s}$ & \\
\hline $1^{\prime}$ & $126.4, \mathrm{CH}$ & $5.16, \mathrm{dm}(10.4)$ & $1^{\prime}, 2^{\prime}, 4^{\prime}$ \\
\hline $2^{\prime}$ & $132.2, \mathrm{C}$ & & $1^{\prime}, 2^{\prime}, 3^{\prime}$ \\
\hline $3^{\prime}$ & $18.0, \mathrm{CH}$ & $2.05, \mathrm{~d}(1.4)$ & $1^{\prime}, 2,9 \mathrm{a} / 7,8,8 \mathrm{a}$ \\
\hline $4^{\prime}$ & $25.9, \mathrm{CH}_{3}$ & $1.73, \mathrm{~d}(1.1)$ & \\
\hline $1-\mathrm{OH} / 8-\mathrm{OH}$ & & $4.88, \mathrm{~s}$ & \\
\hline
\end{tabular}

Compounds 1-3 were evaluated for inhibition of AIP production by the MRSA strain AH1263 at below growth-inhibitory concentrations using a previously validated mass spectrometry-based assay.(38) As shown in Table 3, these compounds suppressed AIP production with $\mathrm{IC}_{50}$ values in the $0.3-12.5 \mu \mathrm{M}$ range. The most potent activity was observed for compound $\mathbf{1}$, with an $\mathrm{IC}_{50}$ of $0.3 \pm 0.1 \mu \mathrm{M}$. The results also indicated that 1 was approximately an order of magnitude more potent than the known AgrA inhibitor $\omega$-hydroxyemodin $(4)(23,24)$ and the positive control ambuic acid.(19,38)

Table 3. Activity of Compounds 1-3 as Inhibitors of agr

\begin{tabular}{|l|l|}
\hline compound & $\mathbf{I C}_{\mathbf{5} 0}(\boldsymbol{\mu M})$ \\
\hline $\mathbf{1}$ & $0.3 \pm 0.1$ \\
\hline $\mathbf{2}$ & $4.6 \pm 2.3$ \\
\hline $\mathbf{3}$ & $6.3-12.5$ \\
\hline $\mathbf{4}$ & $6.3-12.5$ \\
\hline ambuic acid & $1.3 \pm 0.1$ \\
\hline
\end{tabular}

${ }^{\text {a }}$ Positive control.

To further support compound $\mathbf{1}$ as an agr inhibitor, it was evaluated for the inhibition of transcription of the agr effector RNAIII and specific agr-regulated virulence factors, including phenol-soluble modulin alpha ( $p s m \alpha)$ and alpha-hemolysin ( $h l a)$. Previous studies have shown that agr inhibitors enhance host-mediated bacterial clearance during $S$. aureus invasive infections. $(24,41)$ This response is attributed to the inhibition of the $a g r$-regulated virulence factors such as PSMs and hla that target distinct immune cells. Consistent with inhibition of AIP production (Table 3), compound 1 blocked transcription of RNAIII at 9.0 and $16.0 \mu \mathrm{M}$ concentrations (Figure 5). As anticipated based on the inhibition of RNAIII transcription, 
compound 1 also suppressed the transcription of psm $\alpha$ and hla at 2.9,9.0, and $16.0 \mu \mathrm{M}$ concentrations (Figure 5). Notably, bacterial growth was not reduced at these concentrations of 1 (Figure S13). These results indicate that compound 1 inhibits $S$. aureus quorum sensing by disrupting $a g r$ signaling and expression of virulence factors that drive invasive infections.
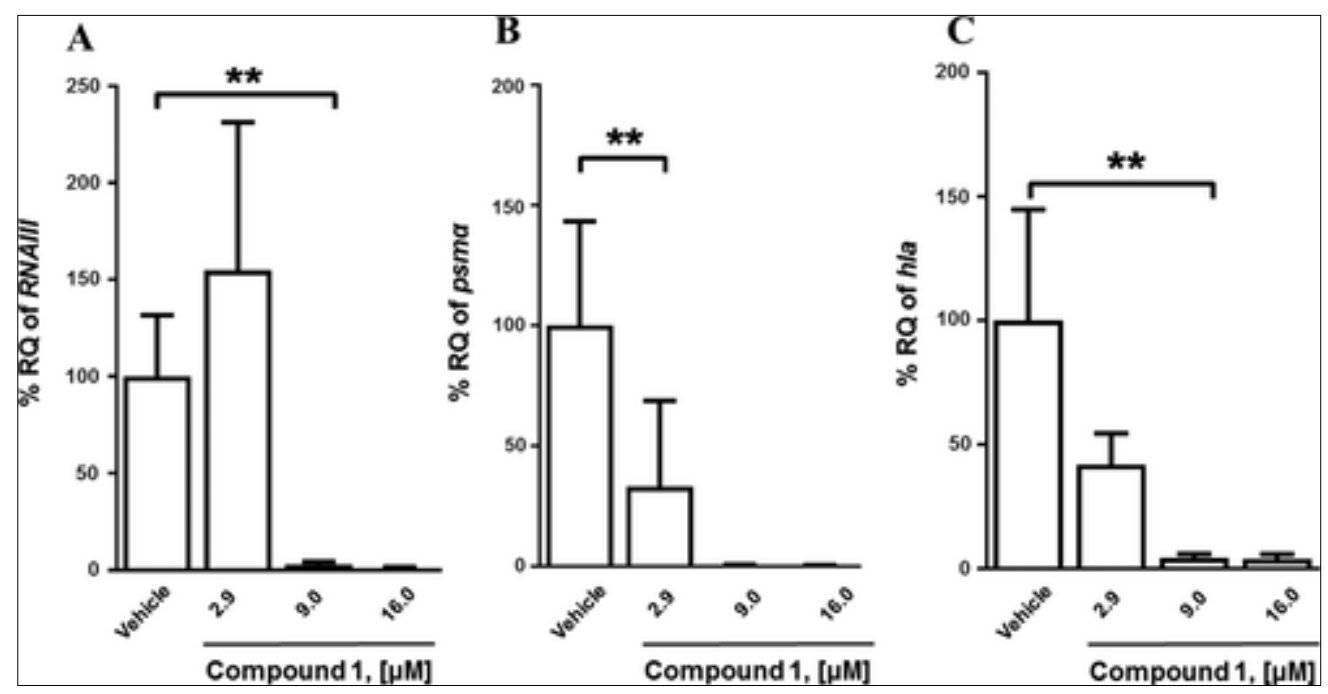

Figure 5. Relative quantification of (A) RNAIII, (B) psma, and (C) hla versus $16 \mathrm{~S}$ rRNA by qRT-PCR following a $5 \mathrm{~h}$ incubation of USA300 LAC $\left(2 \times 10^{7} \mathrm{CFU} / \mathrm{mL}\right)$ and compound 1 or vehicle. Data are represented as a percentage change relative to vehicle control. Data are plotted as the mean \pm SEM of $n=6$ replicates combined from two independent experiments. ${ }^{* *} p<0.01$ based on Mann-Whitney U test.

Due to structural similarities of $\mathbf{1}$ to a fragment compound ( $9 \mathrm{H}$-xanthene-9-carboxylic acid) identified previously as an inhibitor of AgrA,(42) we hypothesized that 1 would be an inhibitor of the AgrA component of the agr quorum sensing system (Figure 1). To predict the mode of inhibition for the compound, the potential binding sites on the crystal structure of the C-terminal AgrA DNA binding domain (AgrAC; PDB ID 4G4K) was evaluated via in silico docking calculations (Figure 6A). Compound 1 was predicted to dock in a pocket (binding energy $(\Delta G)=$ $-5.5 \mathrm{kcal} / \mathrm{mol}$ ) between the side chains of Thr142, Lys146, Phe182, Asn185, Leu189, and Leu192 and formed hydrogen bonds between Glu144 and Leu145 (Figure 6A and B). 


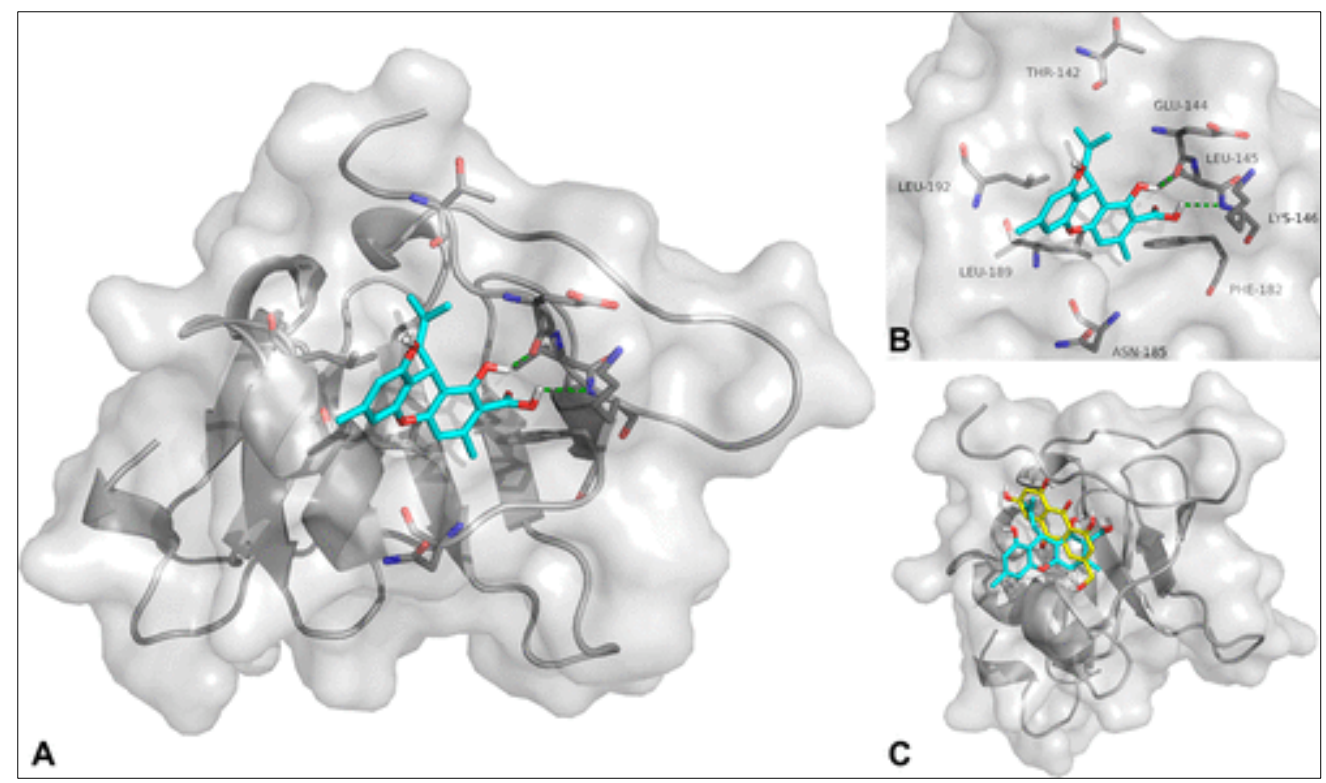

Figure 6. (A) Putative mode of binding for compound 1 on AgrAC crystal structure (PDB ID $4 \mathrm{G} 4 \mathrm{~K}$ ) as predicted by in silico docking calculations. (B) Optimized view of the binding mode for 1. Predicted hydrogen bonds between 1 and the amino acids (Leu145 and Glu144) are indicated by green dashed lines. (C) The known AgrA inhibitor $\omega$-hydroxyemodin (yellow) and compound 1 bound to the same pocket on AgrA .

The polyhydroxyanthraquinone $\omega$-hydroxyemodin (4) is a fungal secondary metabolite that has been shown to have in vivo efficacy against quorum sensing in S. aureus.(24) Comparison of the putative mode of binding of $\mathbf{1}$ and $\mathbf{4}$ on $\mathrm{AgrA}_{\mathrm{C}}$ indicated that these compounds are predicted to have the same potential binding sites on the protein structure (Figure 6C). The calculated binding energy for the best docking pose for 4 was $-5.95 \mathrm{kcal} / \mathrm{mol}$. Compound 4 was observed to bind in a pocket bounded by the side chains of Thr142, Tyr156, Lys146, Gly184, Leu189, and Leu192 and had hydrogen bond interactions with Ile143, Glu144, Asn185, and Glu188.

The similarities in the predicted binding pockets on AgrA $A_{C}$ for compounds $\mathbf{1}$ and $\mathbf{4}$ suggest the potential for the same mode of action of these molecules in suppressing quorum sensing in $S$. aureus. To address this possibility, it will be important to experimentally characterize the mechanism of action of $\mathbf{1}$ with more confirmatory assays as well as with in vivo studies.(24)Overall, the isolation and characterization of the new prenylated diresorcinols 13 from Helotiales sp. highlights the potential of freshwater fungi as a source for new drug leads, even from samples collected in local areas.(31) The identification of the anti-quorum-sensing activity of 1-3, and their excellent potency as compared to previously identified inhibitors, suggests that these compounds may serve as lead compounds for the development of new antivirulence therapeutics against methicillin-resistant $S$. aureus. $(18,41)$

\section{Experimental Section}

\section{General Experimental Procedures}


Melting point data were determined using an SRS DigiMelt melting point apparatus, MPA 160 (Stanford Research Systems), and are uncorrected. Optical rotation data were acquired on a Rudolph Research Autopol III polarimeter. The UV data were acquired using a Varian Cary 100 Bio UV-vis spectrophotometer. The ECD data were collected with an Olis DSM 17 ECD spectrophotometer. IR data were recorded using a PerkinElmer Spectrum One with Universal ATR attachment. The NMR data were collected using either a JEOL ECS-400 spectrometer operating at $400 \mathrm{MHz}$ for ${ }^{1} \mathrm{H}$ and $100 \mathrm{MHz}$ for ${ }^{13} \mathrm{C}$, and equipped with JEOL normal geometry broadband Royal probe, a JEOL ECA-500 spectrometer operating at $500 \mathrm{MHz}$ for ${ }^{1} \mathrm{H}$ and 125 $\mathrm{MHz}$ for ${ }^{13} \mathrm{C}$, or an Agilent $700 \mathrm{MHz}$ NMR spectrometer operating at $700 \mathrm{MHz}$ for ${ }^{1} \mathrm{H}$ and 175 $\mathrm{MHz}$ for ${ }^{13} \mathrm{C}$ and equipped with a cryoprobe. NMR chemical shift values were referenced to the residual $\mathrm{CHCl}_{3}$ singlet at $\delta_{\mathrm{H}} 7.26$ and to the center line of the $\mathrm{CDCl}_{3}$ triplet at $\delta_{\mathrm{C}} 77.2$. HRESIMS data were obtained using a Thermo QExactive Plus mass spectrometer (ThermoFisher) with an electrospray ionization source coupled with a Waters Acquity ultraperformance liquid chromatography (UPLC) system. The HPLC separations were performed using a Varian ProStar HPLC system connected to a ProStar 335 photodiode array detector with UV detection set at 210 and $254 \mathrm{~nm}$. Preparative reversed-phase HPLC purification of samples was performed on an Atlantis Prep T3 $(5 \mu \mathrm{m} ; 250 \times 19 \mathrm{~mm})$ column using a $17 \mathrm{~mL} / \mathrm{min}$ flow rate of the mobile phase consisting of a mixture of $\mathrm{CH}_{3} \mathrm{CN}$ and $\mathrm{H}_{2} \mathrm{O}$ (with $0.1 \% \mathrm{HCOOH}$ ). Flash column chromatography was carried out with a Teledyne ISCO Combiflash Rf connected to both an evaporative light scattering detector and a photodiode array detector with UV set at 200-400 nm.

\section{Fungal Strain Isolation and Identification}

The fungal strain G730 was isolated from a sample of submerged wood, which was collected in March 2015 from a freshwater lake in Hanging Rock State Park, North Carolina (N 36 23.433, W 80 16.64), while attempting to isolate a new genus of freshwater ascomycetes (data not shown). The single spore isolation of the new fungal genus failed, as it was contaminated by hyphal growth from strain G730, which was subsequently purified and isolated using antibiotic water agar (agar $20 \mathrm{~g}$, streptomycin sulfate $250 \mathrm{mg} / \mathrm{L}$, penicillin $\mathrm{G} 250 \mathrm{mg} / \mathrm{L}$, distilled $\mathrm{H}_{2} \mathrm{O} 1 \mathrm{~L}$; antibiotics were added to the molten agar immediately after autoclaving). A culture of strain G730 is preserved in the Department of Chemistry and Biochemistry culture collection at the University of North Carolina at Greensboro. For isolation of freshwater fungi, previously outlined collection and isolation methods by Shearer et al.(43) were implemented.

Morphological examination of fungal cultures grown on different nutrient media types, such as potato dextrose agar (PDA; Difco) and potato carrot agar (Himedia), indicated that strain G730 grew only as sterile mycelia. Fruiting body formation was induced by adding a piece of sterilized balsa to the nutrient media;(43) however, after two/three months of growth, ascoma were not observed on the balsa wood or the PDA plates. Because no morphological data were available for identification of fungal strain G730, molecular sequencing and maximum likelihood phylogenetic analysis were performed as noted in a recent review(44) and as detailed in the Supporting Information. On the basis of an ITS BLAST search and molecular phylogenetic analysis with partial LSU data (Figure S14), strain G730 is tentatively identified as Helotiales sp., Ascomycota. A number of freshwater fungi belonging to the Helotiales have been isolated as aquatic saprobes from submerged wood previously. $(26,45)$ Based on the distant homology to 
ribosomal sequences present in NCBI GenBank, it is likely that strain G730 may represent a previously undescribed taxon; however, since G730 occurs only as sterile mycelia and does not produce any asexual conidia or sexual ascospores, it is conservatively referred to as Helotiales sp. The complete ITS and combined ITS-LSU sequences were deposited in GenBank (accession no. ITS: MK088070, MK088071; ITS-LSU: MK088068, MK088069).

\section{Fermentation, Extraction, and Isolation}

A fresh culture of G730 was grown on PDA and maintained at room temperature (rt). Once good growth was observed (14-21 days), a culture plug was subsequently inoculated into a $10 \mathrm{~mL}$ liquid medium consisting of $2 \%$ soy peptone, $2 \%$ dextrose, and $1 \%$ yeast extract. This was followed by incubation with agitation at $\mathrm{rt}$ for about 7 days using a rotary shaker. Once sufficient fungal growth was observed, the seed culture was used to inoculate a $250 \mathrm{~mL}$ Erlenmeyer flask containing an autoclaved rice medium $\left(10 \mathrm{~g}\right.$ of rice added with $20 \mathrm{~mL}$ of deionized $\left.\mathrm{H}_{2} \mathrm{O}\right)$. The fermentation culture was allowed to grow at $\mathrm{rt}$ for a period of 30 days. Six fermentation cultures of G730 were prepared, and each was extracted by addition of $1: 1 \mathrm{CH}_{3} \mathrm{OH}-\mathrm{CHCl}_{3}(60 \mathrm{~mL})$ with overnight shaking, followed by a combination of the combined filtrates.

To the combined filtrate were added $500 \mathrm{~mL}$ of $\mathrm{CHCl}_{3}$ and $900 \mathrm{~mL}$ of $\mathrm{H}_{2} \mathrm{O}$, the mixture was stirred for $0.5 \mathrm{~h}$, and after partitioning, the $\mathrm{CHCl}_{3}$-soluble layer was collected and dried in vacuo. The resulting extract was further partitioned between $\mathrm{CH}_{3} \mathrm{OH}-\mathrm{CH}_{3} \mathrm{CN}(1: 1,300 \mathrm{~mL})$ and hexanes $(300 \mathrm{~mL})$ to remove lipids, and then the $\mathrm{CH}_{3} \mathrm{OH}-\mathrm{CH}_{3} \mathrm{CN}$-soluble layer was dried in vacuo. The dried material (1.2 g) was adsorbed on Celite 545 and subjected to silica flash chromatography on a $24 \mathrm{~g}$ RediSep Rf Gold Si-gel column, eluting with use of a gradient solvent system of hexane- $\mathrm{CHCl}_{3}-\mathrm{CH}_{3} \mathrm{OH}$ at a flow rate of $35 \mathrm{~mL} / \mathrm{min}$ over 41 column volumes and for a duration of $40 \mathrm{~min}$ to give 100 fractions, each containing approximately $15 \mathrm{~mL}$. The fractions were then pooled according to their ELSD and UV profiles, which resulted in six pools.

Pool $2(556 \mathrm{mg})$ was subjected to preparative reversed-phase HPLC eluting with a linear gradient from $50 \%$ to $60 \% \mathrm{CH}_{3} \mathrm{CN}$ in $\mathrm{H}_{2} \mathrm{O}(0.1 \% \mathrm{HCOOH})$ over 30 min to afford compounds $(4 R)$ regiolone ( $\left.0.5 \mathrm{mg}, t_{\mathrm{R}} 5.5 \mathrm{~min}\right)$, decarboxycitrinone $\left(0.9 \mathrm{mg}, t_{\mathrm{R}} 13 \mathrm{~min}\right), 2\left(7.0 \mathrm{mg}, t_{\mathrm{R}} 26 \mathrm{~min}\right)$, and $1\left(190 \mathrm{mg}, t_{\mathrm{R}} 29 \mathrm{~min}\right)$. The fraction eluting at $t_{\mathrm{R}} 27 \mathrm{~min}(142 \mathrm{mg})$ was repurified using an isocratic condition consisting of $50 \% \mathrm{CH}_{3} \mathrm{CN}$ in $\mathrm{H}_{2} \mathrm{O}(0.1 \% \mathrm{HCOOH})$ over 60 min to afford compound $\mathbf{3}\left(0.9 \mathrm{mg}, t_{\mathrm{R}} 44 \mathrm{~min}\right)$ and more of compounds $2\left(2.4 \mathrm{mg}, t_{\mathrm{R}} 41 \mathrm{~min}\right)$ and $\mathbf{1}$ (115 $\left.\mathrm{mg}, t_{\mathrm{R}} 46 \mathrm{~min}\right)$.

\section{Leotiomycene A (1):}

yellowish-white solid; mp $167-168{ }^{\circ} \mathrm{C} ;[\alpha]^{27} \mathrm{D}+90\left(c 0.1, \mathrm{CH}_{3} \mathrm{CN}\right) ; \mathrm{UV}\left(\mathrm{CH}_{3} \mathrm{CN}\right) \lambda_{\max }(\log \varepsilon)$ 215 (4.5), $291(4.1) \mathrm{nm} ; \mathrm{CD}\left(294 \mu \mathrm{M}, \mathrm{CH}_{3} \mathrm{CN}\right) \lambda_{\max }(\Delta \varepsilon) 209$ (+30.20), $232(-13.52), 282$ $(+3.87) \mathrm{nm}$; IR $v_{\max } 3339,2969,1614,1450,1253,1166,1061 \mathrm{~cm}^{-1} ;{ }^{1} \mathrm{H}$ and ${ }^{13} \mathrm{C}$ NMR, Table 1; HRESIMS $m / z 341.1380[\mathrm{M}+\mathrm{H}]^{+}$(calcd for $\mathrm{C}_{20} \mathrm{H}_{21} \mathrm{O}_{5}, 341.1384$ ).

\section{Leotiomycene B (2):}


white solid; UV $\left(\mathrm{CH}_{3} \mathrm{CN}\right) \lambda_{\max }(\log \varepsilon) 210$ (4.8), 265 (4.2), 307 (3.9) nm; IR $v_{\max } 3419,2923$, $1618,1455,1261,1158,1042 \mathrm{~cm}^{-1} ;{ }^{1} \mathrm{H}$ and ${ }^{13} \mathrm{C}$ NMR, Table 1; HRESIMS $\mathrm{m} / z 343.1530$ [M + $\mathrm{H}]^{+}$(calcd for $\mathrm{C}_{20} \mathrm{H}_{23} \mathrm{O}_{5}, 343.1540$ ).

\section{Leotiomycene C (3):}

white solid; UV $\left(\mathrm{CH}_{3} \mathrm{CN}\right) \lambda_{\max }(\log \varepsilon) 221(4.3), 282(3.3) \mathrm{nm} ;{ }^{1} \mathrm{H}$ and ${ }^{13} \mathrm{C}$ NMR, Table 2; HRESIMS $m / z 297.1480[\mathrm{M}+\mathrm{H}]^{+}$(calcd for $\mathrm{C}_{19} \mathrm{H}_{21} \mathrm{O}_{3}, 297.1485$ ).

\section{AIP Inhibition Assay}

A Synergy H1 Multi-Mode reader (Biotek Instruments, Inc.) was used to obtain optical density $\left(\mathrm{OD}_{600}\right)$ readings. Liquid chromatography-mass spectrometry (LC-MS) was performed using an Acquity ultra-high-performance liquid chromatography (UPLC) system (Waters Corporation) coupled to a Q Exactive Plus Hybrid Quadrupole-Orbitrap mass spectrometer (Thermo Fisher Scientific). The positive control, ambuic acid, was purchased from Adipogen Life Sciences Inc.

Mass spectrometric measurements to evaluate inhibition of AIP production were performed as described previously.(38) Briefly, USA300 LAC (AH1263) (generously supplied by Dr. Alex Horswill, University of Colorado, Anschutz Medical Campus) were cultured in the presence of the test substance in triplicate wells in a 96-well plate format. Bacterial cell growth was monitored at $1 \mathrm{~h}$ intervals by measurement of $\mathrm{OD}_{600}$. At the end of log-phase growth (after a $5 \mathrm{~h}$ incubation period with the sample), the cells were filtered, and the filtrate was analyzed using LC-MS. The $\mathrm{IC}_{50}$ values were determined from a four-parameter logistic function in Sigmaplot (Systat Software Inc.).

\section{Quantitative PCR for $S$. aureus agr-Regulated Gene Transcription}

S. aureus $\mathrm{AH} 1263$ at $2 \times 10^{7} \mathrm{CFU} / \mathrm{mL}$ was grown as $500 \mu \mathrm{L}$ cultures in tryptic soy broth at 37 ${ }^{\circ} \mathrm{C}$ with aeration and the indicated treatments (vehicle versus compound $\mathbf{1}$ ). The bacteria were stored at $-20^{\circ} \mathrm{C}$ in RNAprotect cell reagent, until the RNA purification using RNeasy kits (Qiagen), both according to the manufacturer's recommendations. Quantitative PCR (qPCR) was performed using an ABI ViiA7 real-time PCR system with TaqMan Gene expression master mix (Applied Biosystems) and primer and probe sets for the quantification of $S$. aureus RNAIII, psm $\alpha$, and hlarelative to 16S rRNA (Integrated DNA Technologies).(24)

\section{In Silico Docking on AgrAc}

In silico docking calculations for each ligand (1 and $\mathbf{4}$ ) were performed using the AutoDock 4.0 systems to predict the putative mode of binding on the C-terminal AgrA DNA binding domain $\left(A g r A_{C}\right)$. Compound 1 was prepared by assigning the Gasteiger-Marsili atomic charges and nonpolar hydrogens on the crystal structure of the compound (CCDC 1876593) using AutoDockTools 1.5.4 (http://mgltools.scripps.edu/). Meanwhile, 4 was prepared for docking calculations in the same manner but applying a geometrically optimized structure for the compound. The optimized structure was built using Spartan'10 (www.wavefunction.com) with the optimization performed utilizing the software Gaussian 09 (Gaussian Inc.) at the DFT B3LYP/6-311+G(2d,p) level of theory. On the other hand, the AgrAC crystal structure (RSCB 
Protein Data Bank, PDB ID 4G4K) was set by assigning all the nonpolar hydrogens and Koleman charges to the receptor. A blind docking approach was performed to initiate the prediction, and the best energy obtained was used as the initial conformation for subsequent simulations. Docking studies were performed with Lamarckian Genetic Algorithm (LGA). The grid box for docking was set around a central atom of the ligand with dimensions of $40 \times 40 \times 40$ $\AA$. Parameters were set to an LGA calculation of 100 runs, whereas energy evaluations were set to 2500000 and 27000 generations (repetitions of the process). The resulting docked poses were analyzed with AutoDockTools using cluster analysis, PyMOL.24. Molecular modeling images were prepared using PDB ID 3BS1 and PyMOL.

\section{X-ray Crystal Diffraction Analysis of Compound 1}

A specimen of compound 1, approximate dimensions $0.140 \mathrm{~mm} \times 0.200 \mathrm{~mm} \times 0.300 \mathrm{~mm}$, was used for the X-ray crystallographic analysis. The X-ray intensity data were measured on a Bruker APEX CCD(46) system equipped with a graphite monochromator and a Mo K $\alpha$ sealed tube $(\lambda=$ $0.71073 \AA$ ). The frames were integrated with the Bruker SAINT software(47) package using a narrow-frame algorithm. The integration of the data using a triclinic unit cell yielded a total of 17054 reflections to a maximum $\theta$ angle of $29.99^{\circ}(0.71 \AA$ resolution), of which 9966 were independent (average redundancy 1.711, completeness $=98.7 \%, R_{\text {int }}=2.33 \%, R_{\text {sig }}=4.66 \%$ ), and $8084(81.12 \%)$ were greater than $2 \sigma\left(F^{2}\right)$. The final cell constants of $a=7.3973(5) \AA, b=$ 11.0738(8) $\AA, c=12.0820(9) \AA, \alpha=69.8100(10)^{\circ}, \beta=77.6290(10)^{\circ}, \gamma=77.2120(10)^{\circ}$, volume $=895.52(11) \AA^{3}$ are based upon the refinement of the XYZ-centroids of 4964 reflections above $20 \sigma(I)$. Data were corrected for scaling using the multiscan method (SADABS).(48) The calculated minimum and maximum transmission coefficients (based on crystal size) are 0.9730 and 0.9870 .

The structure was solved and refined using the Bruker SHELXTL software package, using the space group $P 1$, with $Z=2$ for the formula unit, $\mathrm{C}_{20} \mathrm{H}_{20} \mathrm{O}_{5}$. The final anisotropic full-matrix least-squares refinement on $F^{2}$ with 465 variables converged at $R_{1}=4.63 \%$, for the observed data and $w R_{2}=12.30 \%$ for all data. The goodness-of-fit was 1.040 . The final structural model was refined as an inversion twin with a BASF value of 0.4(8). The largest peak in the final difference electron density synthesis was $0.334 \mathrm{e}^{-} / \AA^{3}$, and the largest hole was $-0.207 \mathrm{e}^{-} / \AA^{3}$ with an RMS deviation of $0.043 \mathrm{e}^{-} / \AA^{3}$. On the basis of the final model, the calculated density was 1.262 $\mathrm{g} / \mathrm{cm}^{3}$ and $F(000), 360 \mathrm{e}^{-}$. Crystal data, data collection, and structure refinement details are summarized in the Supporting Information. The X-ray crystallographic data for $\mathbf{1}$ have been deposited with the Cambridge Crystallographic Data Center under accession number CCDC 1876593. These data can be accessed free of charge at http://www.ccdc.cam.ac.uk/.

\section{Computational Details}

The TDDFT calculations, such as ECD and optical rotation, were performed as described previously utilizing the Gaussian'09 program package.(49) A 3D model of 1 was built and geometry optimized using Spartan'10 software (www.wavefunction.com). Conformational analysis was performed by a Monte Carlo search protocol as implemented in the same software under the semiempirical method (PM3). The resulting conformers were filtered, checked for 
duplicity, and minimized using a DFT force field at the B3LYP/6-311+G(2d,p) level of theory. ECD calculations using the self-consistent reaction field with conductor-like continuum solvent model in $\mathrm{CH}_{3} \mathrm{CN}$ were subsequently performed on the obtained DFT-minimized major conformers of both $9 R$ and $9 S$ enantiomers of compound 1 . Subsequently, the excitation energy $(\mathrm{nm})$ and rotatory strength $(R)$ in dipole velocity $\left(R_{\mathrm{vel}}\right)$ and dipole length $\left(R_{\text {len }}\right)$ forms obtained from the calculations were then used to simulate the ECD curves.

\section{Supporting Information}

The Supporting Information is available free of charge on the ACS Publications website at DOI: 10.1021 acs.jnatprod.8b00925.

- NMR spectra of isolated compounds, the phylogram of the most likely tree from partial LSU sequence data ( $830 \mathrm{bp}$ ) from strain G730, crystal data, data collection, and refinement details for compound $\mathbf{1}$ (PDF)

- X-ray crystallographic data (CIF)

The authors declare no competing financial interest.

\section{Acknowledgments}

NMR studies were performed in part at the Joint School of Nanoscience and Nanoengineering, a member of the Southeastern Nanotechnology Infrastructure Corridor (SENIC) and National Nanotechnology Coordinated Infrastructure (NNCI), which is supported by the National Science Foundation (grant ECCS-1542174). The WFU X-ray Facility thanks the National Science Foundation (grant CHE-0234489) for funds to purchase the X-ray instrument and computers. We thank T. N. Graf (UNCG) for helpful suggestions on the manuscript and A. Scott (UNCG) for assistance with the graphical abstract.

Dedication

Dedicated to Dr. Rachel Mata, of the National Autonomous University of Mexico, Mexico City, Mexico, and to Dr. Barbara N. Timmermann, of the University of Kansas, for their pioneering work on bioactive natural products.

\section{References}

This article references 49 other publications.

1. Mediavilla, J. R.; Chen, L.; Mathema, B.; Kreiswirth, B. N. Curr. Opin. Microbiol. 2012, 15, 588- 595, DOI: 10.1016/j.mib.2012.08.003

2. David, M. Z.; Daum, R. S. Clin. Microbiol. Rev. 2010, 23, 616-687, DOI: 10.1128/CMR.00081-09

3. Kock, R.; Becker, K.; Cookson, B.; van Gemert-Pijnen, J. E.; Harbarth, S.; Kluytmans, J.; Mielke, M.;Peters, G.; Skov, R. L.; Struelens, M. J.; Tacconelli, E.; Navarro Torne, A.; Witte, W.; Friedrich, A. W.Eurosurveillance 2010, 15, 19688, DOI: 10.2807/ese.15.41.19688-en 
4. Chen, C. J.; Huang, Y. C. Clin. Microbiol. Infect. 2014, 20, 605-23, DOI: 10.1111/14690691.12705

5. Centers for Disease Control and Prevention. Antibiotic/Antimicrobial Resistance. https://www.cdc.gov/drugresistance/biggest_threats.html (accessed April 21, 2017).

6. The White House. Executive Order 13676: Combating Antibiotic-Resistant Bacteria. Fed. Regist. 2014, 184, 56931-5.

7. World Health Organization. WHO Publishes List of Bacteria for Which New Antibiotics Are Urgently Needed. http://www.who.int/mediacentre/news/releases/2017/bacteriaantibiotics-needed/en/ (accessed April 21,2017).

8. Maura, D.; Ballok, A. E.; Rahme, L. G. Curr. Opin. Microbiol. 2016, 33, 41-46, DOI: 10.1016/j.mib.2016.06.001

9. Rasko, D. A.; Sperandio, V. Nat. Rev. Drug Discovery 2010, 9, 117-128, DOI: $10.1038 / \operatorname{nrd} 3013$

10. Yang, T.; Tal-Gan, Y.; Paharik, A. E.; Horswill, A. R.; Blackwell, H. E. ACS Chem. Biol. 2016, 11, 1982-1991, DOI: 10.1021/acschembio.6b00120

11. Tal-Gan, Y.; Ivancic, M.; Cornilescu, G.; Cornilescu, C. C.; Blackwell, H. E. J. Am. Chem. Soc. 2013, 135,18436-18444, DOI: 10.1021/ja407533e

12. Cegelski, L.; Marshall, G. R.; Eldridge, G. R.; Hultgren, S. J. Nat. Rev. Microbiol. 2008, 6, 17-27, DOI: 10.1038/nrmicro1818

13. George, E. A.; Muir, T. W. ChemBioChem 2007, 8, 847-855, DOI: 10.1002/cbic. 200700023

14. Czaplewski, L.; Bax, R.; Clokie, M.; Dawson, M.; Fairhead, H.; Fischetti, V. A.; Foster, S.; Gilmore, B. F.;Hancock, R. E. W.; Harper, D.; Henderson, I. R.; Hilpert, K.; Jones, B. V.; Kadioglu, A.; Knowles, D.;Ólafsdóttir, S.; Payne, D.; Projan, S.; Shaunak, S.; Silverman, J.; Thomas, C. M.; Trust, T. J.; Warn, P.;Rex, J. H. Lancet Infect. Dis. 2016, 16, 239- 251, DOI: 10.1016/S1473-3099(15)00466-1

15. Thoendel, M.; Kavanaugh, J. S.; Flack, C. E.; Horswill, A. R. Chem. Rev. 2011, 111, 117- 151, DOI: 10.1021/cr100370n

16. Cheung, G. Y.; Wang, R.; Khan, B. A.; Sturdevant, D. E.; Otto, M. Infect. Immun. 2011, 79, 1927- 35, DOI: 10.1128/IAI.00046-11

17. Queck, S. Y.; Jameson-Lee, M.; Villaruz, A. E.; Bach, T.-H. L.; Khan, B. A.; Sturdevant, D. E.;Ricklefs, S. M.; Li, M.; Otto, M. Mol. Cell 2008, 32, 150- 158, DOI: 10.1016/j.molcel.2008.08.005

18. Cech, N. B.; Horswill, A. R. Future Microbiol. 2013, 8, 1511-1514, DOI: 10.2217/fmb.13.134 
19. Todd, D. A.; Parlet, C. P.; Crosby, H. A.; Malone, C. L.; Heilmann, K. P.; Horswill, A. R.; Cech, N. B.Antimicrob. Agents Chemother. 2017, 61, e00263-17, DOI: 10.1128/AAC.00263-17

20. Newman, D. J.; Cragg, G. M. J. Nat. Prod. 2016, 79, 629-661, DOI: 10.1021/acs.jnatprod.5b01055

21. Cragg, G. M.; Newman, D. Biochim. Biophys. Acta, Gen. Subj. 2013, 1830, 3670-3695, DOI: 10.1016/j.bbagen.2013.02.008

22. Nakayama, J.; Uemura, Y.; Nishiguchi, K.; Yoshimura, N.; Igarashi, Y.; Sonomoto, K. Antimicrob. Agents Chemother. 2009, 53, 580- 586, DOI: 10.1128/AAC.00995-08

23. Figueroa, M.; Jarmusch, A. K.; Raja, H. A.; El-Elimat, T.; Kavanaugh, J. S.; Horswill, A. R.; Cooks, R. G.;Cech, N. B.; Oberlies, N. H. J. Nat. Prod. 2014, 77, 1351-1358, DOI: $10.1021 / \mathrm{np} 5000704$

24. Daly, S. M.; Elmore, B. O.; Kavanaugh, J. S.; Triplett, K. D.; Figueroa, M.; Raja, H. A.; El-Elimat, T.;Crosby, H. A.; Femling, J. K.; Cech, N. B.; Horswill, A. R.; Oberlies, N. H.; Hall, P. R. Antimicrob. Agents Chemother. 2015, 59, 2223-2235, DOI: 10.1128/AAC.04564-14

25. Frey-Klett, P.; Burlinson, P.; Deveau, A.; Barret, M.; Tarkka, M.; Sarniguet, A. Microbiol. Mol. Biol. Rev. 2011,75, 583-609, DOI: 10.1128/MMBR.00020-11

26. Shearer, C. A.; Raja, H. A. Freshwater Ascomycetes Database: http://fungi.life.illinois.edu/ (accessed March 1, 2017).

27. Shearer, C. A.; Descals, E.; Kohlmeyer, B.; Kohlmeyer, J.; Marvanová, L.; Padgett, D.; Porter, D.;Raja, H. A.; Schmit, J. P.; Thorton, H. A.; Voglymayr, H. Biodivers. Conserv. 2007, 16, 49- 67, DOI: 10.1007/s10531-006-9120-z

28. Vijaykrishna, D.; Jeewon, R.; Hyde, K. D. Fungal Divers. 2006, 23, 351- 390

29. Shearer, C. A. Nova Hedwigia 1993, 56, 1- 33

30. El-Elimat, T.; Raja, H. A.; Figueroa, M.; Falkinham, J. O., 3rd; Oberlies, N. H. Phytochemistry 2014, 104,114 - 120, DOI: 10.1016/j.phytochem.2014.04.006

31. El-Elimat, T.; Raja, H. A.; Day, C. S.; Chen, W. L.; Swanson, S. M.; Oberlies, N. H. J. Nat. Prod. 2014, 77,2088-2098, DOI: 10.1021/np500497r

32. Raja, H. A.; Oberlies, N. H.; Figueroa, M.; Tanaka, K.; Hirayama, K.; Hashimoto, A.; Miller, A. N.;Zelski, S. E.; Shearer, C. A. Mycologia 2013, 105, 959- 976, DOI: $10.3852 / 12-313$

33. El-Elimat, T.; Raja, H. A.; Day, C. S.; McFeeters, H.; McFeeters, R. L.; Oberlies, N. H. Bioorg. Med. Chem.2017, 25, 795-804, DOI: 10.1016/j.bmc.2016.11.059 
34. Raja, H. A.; El-Elimat, T.; Oberlies, N. H.; Shearer, C. A.; Miller, A. N.; Tanaka, K.; Hashimoto, A.;Fournier, J. Mycologia 2015, 107, 845- 862, DOI: 10.3852/15-013

35. Crous, P. W.; Wingfield, M. J.; Burgess, T. I.; Hardy, G. E. S. J.; Crane, C.; Barrett, S.; Cano-Lira, J. F.;Le Roux, J. J.; Thangavel, R.; Guarro, J.; Stchigel, A. M.; Martín, M. P.; Alfredo, D. S.; Barber, P. A.;Barreto, R. W.; Baseia, I. G.; Cano-Canals, J.; Cheewangkoon, R.; Ferreira, R. J.; Gené, J.; Lechat, C.;Moreno, G.; Roets, F.; Shivas, R. G.; Sousa, J. O.; Tan, Y. P.; Wiederhold, N. P.; Abell, S. E.; Accioly, T.;Albizu, J. L.; Alves, J. L.; Antoniolli, Z. I.; Aplin, N.; Araújo, J.; Arzanlou, M.; Bezerra, J. D. P.;Bouchara, J. P.; Carlavilla, J. R.; Castillo, A.; Castroagudín, V. L.; Ceresini, P. C.; Claridge, G. F.; Coelho, G.;Coimbra, V. R. M.; Costa, L. A.; da Cunha, K. C.; da Silva, S. S.; Daniel, R.; de Beer, Z. W.; Dueñas, M.;Edwards, J.; Enwistle, P.; Fiuza, P. O.; Fournier, J.; García, D.; Gibertoni, T. B.; Giraud, S.;Guevara-Suarez, M.; Gusmão, L. F. P.; Haituk, S.; Heykoop, M.; Hirooka, Y.; Hofmann, T. A.; Houbraken, J.;Hughes, D. P.; Kautmanová, I.; Koppel, O.; Koukol, O.; Larsson, E.; Latha, K. P. D.; Lee, D. H.;Lisboa, D. O.; Lisboa, W. S.; López-Villalba, Á.; Maciel, J. L. N.; Manimohan, P.; Manjón, J. L.;Marincowitz, S.; Marney, T. S.; Meijer, M.; Miller, A. N.; Olariaga, I.; Paiva, L. M.; Piepenbring, M.;Poveda-Molero, J. C.; Raj, K. N. A.; Raja, H. A.; Rougeron, A.; Salcedo, I.; Samadi, R.; Santos, T. A. B.;Scarlett, K.; Seifert, K. A.; Shuttleworth, L.; Silva, G. A.; Silva, M.; Siqueira, J. P. Z.; Souza-Motta, C. M.;Stephenson, S. L.; Sutton, D. A.; Tamakeaw, N.; Telleria, M. T.; Valenzuela-Lopez, N.; Viljoen, A.;Visagie, C. M.; Vizzini, A.; Wartchow, F.; Wingfield, B. D.; Yurchenko, E.; Zamora, J. C.; Groenewald, J. Z.Persoonia 2016, 37, 218-403, DOI: $10.3767 / 003158516$ X694499

36. Paguigan, N. D.; Raja, H. A.; Day, C. S.; Oberlies, N. H. Phytochemistry 2016, 126, 59- 65, DOI: 10.1016/j.phytochem.2016.03.007

37. Boles, B. R.; Thoendel, M.; Roth, A. J.; Horswill, A. R. PLoS One 2010, 5, e10146 DOI: 10.1371/journal.pone.0010146

38. Todd, D. A.; Zich, D. B.; Ettefagh, K. A.; Kavanaugh, J. S.; Horswill, A. R.; Cech, N. B. J. Microbiol. Methods2016, 127, 89- 94, DOI: 10.1016/j.mimet.2016.05.024

39. Talapatra, S. K.; Karmacharya, B.; De, S. C.; Talapatra, B. Phytochemistry 1988, 27, 3929- 3932, DOI: 10.1016/0031-9422(88)83047-4

40. Whyte, A. C.; Gloer, J. B.; Scott, J. A.; Malloch, D. J. Nat. Prod. 1996, 59, 765- 769, DOI: 10.1021/np9603232

41. Sully, E. K.; Malachowa, N.; Elmore, B. O.; Alexander, S. M.; Femling, J. K.; Gray, B. M.; DeLeo, F. R.;Otto, M.; Cheung, A. L.; Edwards, B. S.; Sklar, L. A.; Horswill, A. R.; Hall, P. R.; Gresham, H. D. PLoS Pathog. 2014, 10, e1004174 DOI: 10.1371/journal.ppat.1004174

42. Leonard, P. G.; Bezar, I. F.; Sidote, D. J.; Stock, A. M. Biochemistry 2012, 51, 10035- 10043, DOI: 10.1021/bi3011785 
43. Shearer, C. A.; Langsam, D. M.; Longcore, J. E. In Measuring and Monitoring Biological Diversity: Standard Methods for Fungi; Mueller, G. M.; Bills, G. F.; Foster, M. S., Eds.; Smithsonian Institution Press:Washington, D.C, 2004; pp 513- 531.

44. Raja, H. A.; Miller, A. N.; Pearce, C. J.; Oberlies, N. H. J. Nat. Prod. 2017, 80, 756- 770, DOI: 10.1021/acs.jnatprod.6b01085

45. Raja, H. A.; Miller, A. N.; Shearer, C. A. Mycologia 2008, 100, 141-148, DOI: 10.3852/mycologia.100.1.141

46. Bruker APEX2 version 2014.11-0; Bruker AXS Inc.: Madison, WI, 2014.

47. Bruker SAINT version 8.34A; Bruker AXS Inc.: Madison, WI, 2014.

48. Krause, L.; Herbst-Irmer, R.; Sheldrick, G. M.; Stalke, D. J. J. Appl. Crystallogr. 2015, 48, 3- 10, DOI: 10.1107/S1600576714022985

49. Rivera-Chávez, J.; Figueroa, M.; González, M. d. C.; Glenn, A. E.; Mata, R. J. J. Nat. Prod. 2015, 78, 730-735, DOI: $10.1021 / \mathrm{np500897y}$ 